\title{
Chronological History and Destruction Pattern of Tornados in Bangladesh
}

\author{
Md. Shahadat Hosen", Abu Jubayer \\ Institute of Water and Flood Management, Bangladesh University of Engineering and Technology, Dhaka, Bangladesh
}

Email address:

shahadat59@gmail.com (Md. S. Hosen)

*Corresponding author

\section{To cite this article:}

Md. Shahadat Hosen, Abu Jubayer. Chronological History and Destruction Pattern of Tornados in Bangladesh. American Journal of Environmental Protection. Vol. 5, No. 4, 2016, pp. 71-81. doi: 10.11648/j.ajep.20160504.11

Received: May 1, 2016; Accepted: May 27, 2016; Published: June 18, 2016

\begin{abstract}
Bangladesh has been facing the severe tornado incidents from the historical ages due to its geographical location. In recent years, it becomes more frequent; even hit the land more than six times in a year. The study has been conducted based on critical review and analysis of secondary data. This review paper has been carried out to recognize the chronology and frequency within a certain period of time to identify the destruction pattern of tornadoes in the country. From 1865-2014 the country has been faced more than 250 tornadoes reported, in which 20 events or more were enormously deadliest in fatalities and damages in the world history. Within these, 116 events has been recorded minimum 01 life lose. The recounted data figured out these events causes more than 9667 no. of human lives lost, injured 74702 and affected another 586306 lives of human. The regularity of tornado increases last few decades, basically after 1960. Sequential development of human civilization with global warming inspires the amount of warm and dry air is that responsible for tornado occurrence. During the tornado, the heavy rainfall is formed for moist weather which contains huge water drops. Sudden large runoff pollutes the existing local water system and the crop lands in the affected area. Improved weather forecasting, warning system, tornado risk zoning maps and ensuring proper building code for infrastructure may help to reduce the losses.
\end{abstract}

Keywords: Chronology, Destruction Pattern, Fatalities, Frequency, Risk Map, Tornado

\section{Introduction}

Bangladesh is the most vulnerable country to several natural disasters due to its geographical location. Every year these natural calamities destroy the locality in some part of the country. The Tornado is one of the natural disasters which occurred instantly within a short period of time but keep a large devastating footage. Bangladesh has a long history of tornado incidents. The first reported tornado in the country occurred in March 1875 [11]. The two transitional periods between south-west and northeast monsoons over the Indian sub-continent are characterized by severe local storms. The transitional periods are usually referred to as pre-monsoon (March-May) and post-monsoon (October-November). It is the pre-monsoon period when most of the abnormal rainfall or drought conditions frequently occur in different parts of Bangladesh. Also, there are severe seasonal, local storms, popularly known as
Nor'westers (kalbaishakhi). Severe Nor'westers is generally associated with tornadoes. The Tornadoes are embedded within a mother thundercloud and moves along the direction of the squall of the mother storm. The maximum frequency of devastating tornado usually occurs in April [50], while a few in May and minimum in March. Nor'westers and tornadoes are more frequent in the afternoon [26] [8] [48] [50]. After a careful review of newspaper reports, Ono (2001) [34] claims that Bangladesh experienced 191 tornadoes between 1967 and 1996 whereas more than 100 tornadoes causes the loss of human life. This represents an average of 6.4 tornadoes per year. Although he found no linear trend in terms of the number of reported tornadoes over that period [34]. The available evidence suggests that the frequency of tornadoes has increased in recent years. According to the Bangladesh Disaster Report, 15 tornadoes occurred in 1998 [2] [3]. A cyclone continues for days, whereas a tornado persists for a very short period of time. Tornadoes often form a series and travel in almost 
parallel paths. Choudhury et al. (2003) [7] describe, the whole tornado moves at a speed of 25-30 miles/hour whereas the maximum wind in a tornado could be 300 miles/hour. These tornadoes accounted for about 60 percent of all tornados reported. Day by day this devastation rate is turning high due to population explosion and extremely weak infrastructure with low quality building materials.

\section{Objectives}

The review study focuses on the following objectives-

- To know the chronology and destruction pattern of tornadoes that affects the local people in Bangladesh.

- To find out the mitigating arrangements to reduce the damages due to tornados in rural Bangladesh.

\section{Methodology}

We have followed the secondary data collection and review method to attain the study objectives. We surveyed the various available data sources based on the published news on tornadoes in locally/nationally/internationally published newspapers, country disaster report, emergency response report, peer reviewed internationally scientific articles, annual report of relevant authority. The same approach has been followed by the many researchers widely (Yamane et al. (2009)). Niino et al. (1997) developed the climatology of tornadoes in Japan based on the survey of newspapers and reports compiled by the Japan Meteorological Agency [49]. Yamane et al. (2009), Finch, J. D. (2005) have followed the same approach. We have collected the existing national \& international literature on tornado in Bangladesh available from the various sources. Exploring the information from the existing journals, newspapers, books and thesis papers to find out and assemble the significant findings solely the data related the fatal tornado events with minimum life loss. We also cross check the tornado events very carefully to avoid the double counting and ignored the events without human fatalities. We try to find out the event specific location, fatalities, property damages etc. against the individual events to ensure the devoid of overlapping and proper database formation. We surveyed the major daily newspaper included the Bangladesh Observer (BO), the United News of Bangladesh (UNB), Bangladesh Sangbad Sangstha (BSS), the Daily Star, the Daily Ittefaq, the Pakistan Observer (PO). We collect the records \& documents from Bangladesh Meteorological Department (BMD), and Disaster Management Bureau (DMB), Bangladesh district Gazetteer (BDG), International Federation of Red Cross (IFRC) \& Red Crescent Societies (RCS) for their joint disaster report, international website database, and combined disasters preparedness report etc. We also went through the different non-Govt. Organization official documents, who worked with the emergency disaster response. After carefully reviewed all these materials we produced a fatal tornado database based on the historical chronology, death toll and property damages. All information that is extracted briefly highlighting the study objectives by analyzing and synthesizing.

\section{Discussions and Analysis}

\subsection{Formation of Tornado}

A Tornado formation is the cause of the interaction of two air masses, one moist and warm air and the other dry and cold air resulting in an extreme form of instability (Figure 1). It forms when two large air masses of varying temperature and humidity collide, with warm air in lower layer and cold air in upper layer [41]. The Tornadoes often develop from a class of thunderstorms known as Supercells. Supercells contain meso-cyclones, an area of organized rotation a few miles up in the atmosphere, usually 1-6 miles $(2-10 \mathrm{~km})$ across [41]. In addition to tornadoes, heavy rain, frequent lightning, strong wind gusts, and hail are common in such storms. Most intense tornadoes (EF3 to EF5 on Enhanced Fujita Scale) develop from Supercells and followed a recognizable life cycle [13]. That begins when increasing rainfall drags with it an area of quickly descending air known as the Rear Flank Downdraft (RFD). This downdraft accelerates as it approaches the ground, and drags the Super cells rotating meso-cyclone towards the ground with it [41].
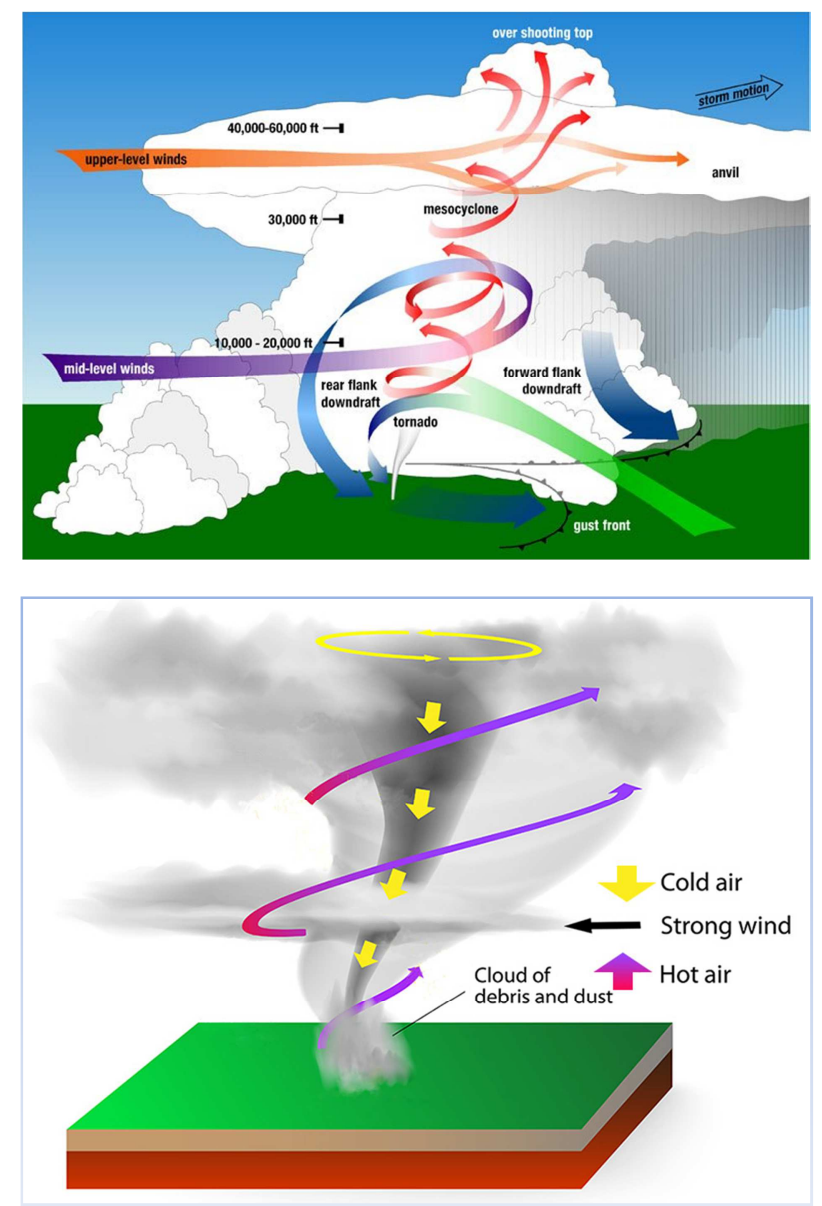

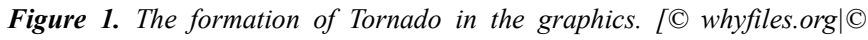
weather.gov].

\subsection{Types of Tornado}

Most of the tornadoes take on the appearance of a narrow funnel, a few hundred yards (meters) across, with a small 
cloud of debris near the ground. The Tornadoes may be obscured completely by rain or dust. These tornadoes are especially dangerous, as even experienced meteorologists might not see them [47]. The Tornadoes can appear in many shapes and sizes. According Russian international news agency (sputnik news/RIANOVOSTI, 2010) [41], they classify the tornado in three broad classes based on the shape. They are water spout, land spout and multiple vortex. They describe the tornadoes as water spout is the most common types, land spout is the tornado whose diameter can exceed its height and the multiple vortex is the most powerful one that causes heavy damages [41]. Like hurricanes and tropical storms, tornadoes and the severe thunderstorms from which they usually develop come in a wide array of shapes and sizes. They can vary from weak tornadoes (which are the most common variety) to extremely strong and large monster tornadoes, which can stretch a mile wide or more. The National Severe Storms Laboratory -- a division of the National Weather Service (USA) that monitors severe storms and tornadoes -- has assembled the following facts and statistics about tornadoes from their decades of research in terms of the damages intensity:

Weak tornadoes: Weak Tornadoes Comprise $69 \%$ of all tornadoes, They Cause less than $5 \%$ of all tornado deaths, Have a lifetime of between 1-10 minutes, The Wind speeds measured at less than 110 miles/hour.

Strong tornadoes: Strong Tornadoes Comprise 29\% of all tornadoes, They Cause nearly $30 \%$ of all tornado deaths, their life span may last 20 minutes or longer, The Wind speeds measured at between 110-205 miles/hour.

Violent tornadoes: The violent Tornadoes Comprise $2 \%$ of all tornadoes, They Cause $70 \%$ of all tornado deaths, they have a lifetime of 1 hour or longer, The Wind speeds measured more than 205 miles/hour.

Table 1. Fujita Tornado Damage Scale Developed in 1971 by T. Theodore Fujita of the University of Chicago [13].

\begin{tabular}{|c|c|c|c|}
\hline Scale & Category & Miles/hour & Expected Damages \\
\hline F0 & Weak & $40-72$ & $\begin{array}{l}\text { Light: signboard/billboard damages, } \\
\text { tree branches broken }\end{array}$ \\
\hline F1 & & $73-112$ & $\begin{array}{l}\text { Moderate: damages windows, trees } \\
\text { snapped }\end{array}$ \\
\hline $\mathrm{F} 2$ & Strong & $113-157$ & $\begin{array}{l}\text { Considerable: destroy weak } \\
\text { structure, uproot large trees }\end{array}$ \\
\hline F3 & & $158-206$ & $\begin{array}{l}\text { Severe: cars overturned, trees } \\
\text { leveled, collapse wall from buildings }\end{array}$ \\
\hline F4 & Violent & $207-260$ & Devastating: frame house destroyed \\
\hline F5 & & $261-318$ & $\begin{array}{l}\text { autos moved over } 100 \text { meters, steel } \\
\text { reinforced structures highly damaged }\end{array}$ \\
\hline
\end{tabular}

\subsection{Movement of Tornado}

The forward speed of Bengal tornadoes could only be ascertained in a little cases and the direction of movement could be determined in about half cases. The preferred movement was to the southeast or south- southeast. A few of the tornadoes moved to the south, and a few to the east or northeast [11]. The paths were not always along the straight line. The Manikgonj tornado on April 1973 moved in a zigzag fashion to the southeast [19]. The Saturia-Daulatpur tornado on April 1989 initially moved to east, then hooked north before lifting (BMD Memo 1989). The Calcutta tornado on April 1838 that ravaged the eastern suburbs of Calcutta had a classic motion of south-southeast [12] that makes it a very unusual tornado is the 2.5 hours it took to traverse the 16 mile path. There is generally not enough information to determine the speed of the tornadoes. In fact the speed has been documented for only two tornadoes, and these were based on the ground surveys. The Tangail tornado on May 1996 moved about 40-45 $\mathrm{km}$ /hour to the south-southeast [33], while the Cooch Behar tornado on April 1963 moved about $75 \mathrm{~km} /$ hour to the Eastsoutheast (Nandi and Mukherjee) [31].


Figure 2. Movement of Tornados in Bengal region. [C Bangladeshtornadoes.org/surface].

\subsection{History of Tornadoes in Bangladesh}

The first reported tornado occurred in the country in March 1875 [11] [16] [39] [42] in Mymensingh but available evidence (Table 2) indicate that two or more tornado occurred in anonymous location of the country that caused human fatalities [5] [16] [42]. Furthermore, According to the 
newspaper review reports, Ono [34] claims that Bangladesh has experienced more than 191 tornadoes between 1967 and 1996. In the same way, she also affected with numerous tornadoes that reported various sources like newspapers, Govt. \& non-Govt. Organization official documents, international website database, and combined disasters preparedness report, etc. We have explored the tornado events very sensitively and carefully from the all other similar local convective severe storms as Nor'westers \& others. We have separated the tornadic and non-tornadic events very carefully by checking $\&$ cross checking the noted sources. According to all available data sources a database of fatal tornados (events with life loss) has been produced according to the chronological order of historical time with the event location and devastation. We overlooked carefully the events without fatalities.

Table 2. Chronological History of Tornados in Bangladesh with the various affected scenario.

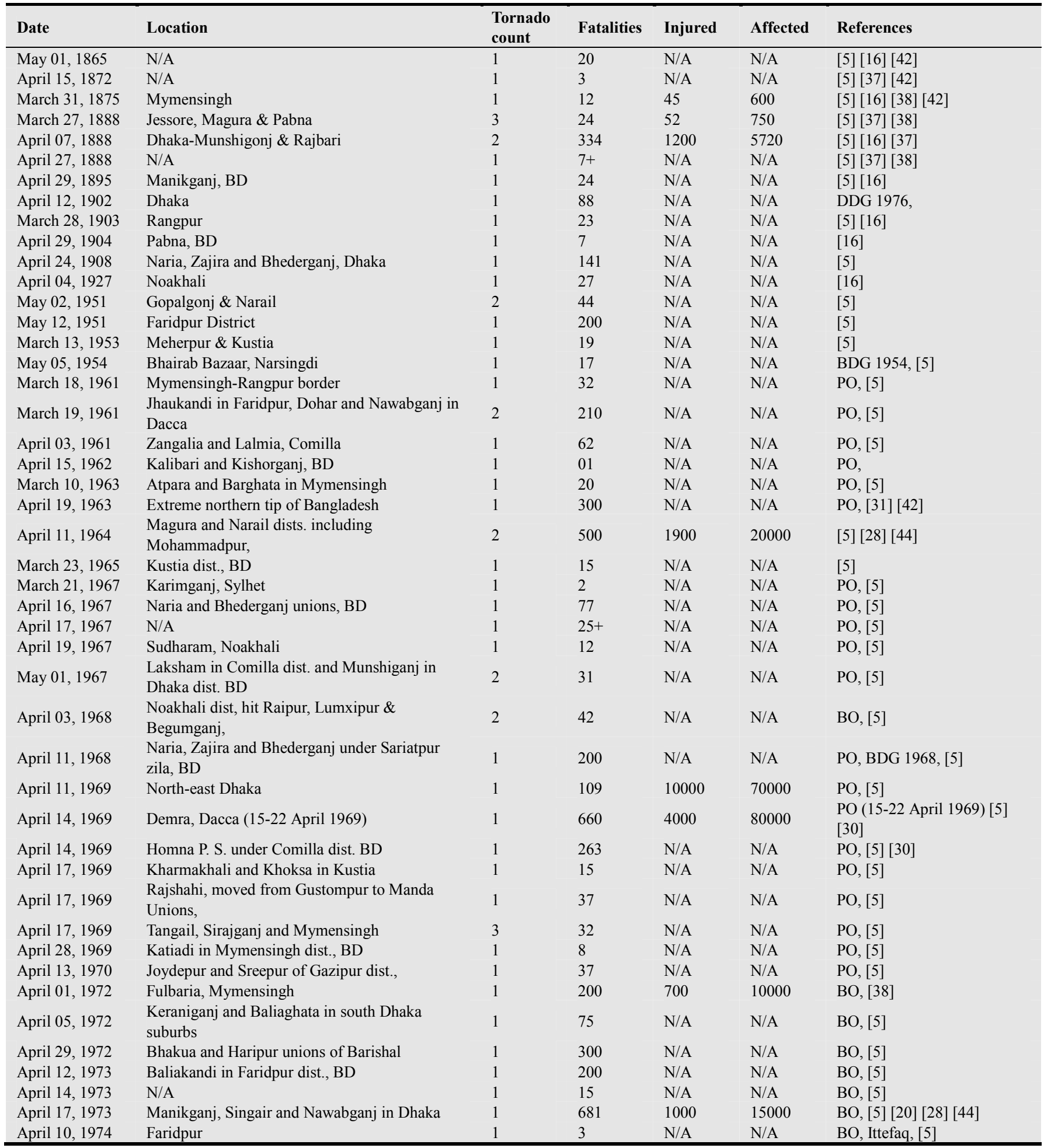




\begin{tabular}{|c|c|c|c|c|c|c|}
\hline Date & Location & $\begin{array}{l}\text { Tornado } \\
\text { count }\end{array}$ & Fatalities & Injured & Affected & References \\
\hline April 11, 1974 & 11 miles $\mathrm{W}$ of Bogra, & 1 & 100 & $\mathrm{~N} / \mathrm{A}$ & $\mathrm{N} / \mathrm{A}$ & $\mathrm{BO},[20]$ \\
\hline April 10, 1976 & Naria and Bhederganj under Sariatpur zila, & 1 & 46 & N/A & N/A & $\mathrm{BO},[5][20]$ \\
\hline May 08,1976 & Hatiya Island, Noakhali & 1 & 2 & N/A & N/A & $\mathrm{BO},[5]$ \\
\hline May 09,1976 & Narayanganj \& S. suburbs of Dacca, & 1 & 1 & N/A & N/A & $\mathrm{BO},[20]$ \\
\hline March 31, 1977 & $\begin{array}{l}\text { Lahund and Dangargaon villages in Katiadi, } \\
\text { Narsingdi }\end{array}$ & 1 & 17 & N/A & N/A & $\mathrm{BO},[5]$ \\
\hline April 01, 1977 & Madaripur \& Shibchar, & 1 & 500 & 600 & 18000 & $\mathrm{BO},[1][33][28][44]$ \\
\hline April 02, 1977 & $\begin{array}{l}\text { Gopalgonj-Faridpur Mokshedpur, Bhanga and } \\
\text { Tungipara }\end{array}$ & 2 & 111 & N/A & N/A & $\mathrm{BO},[5]$ \\
\hline April 16, 1978 & Mymensingh & 1 & 150 & $\mathrm{~N} / \mathrm{A}$ & N/A & Ittefaq, [17] \\
\hline May 07,1979 & Jamalpur, & 1 & 5 & N/A & N/A & BDG, [5] \\
\hline March 01, 1981 & Itna, Kishorgonj & 1 & 15 & N/A & N/A & $\mathrm{BO},[5]$ \\
\hline April 12, 1981 & $\begin{array}{l}\text { Parshuram, Fulgazi, Somarpur, and Sonagazi in } \\
\text { Feni }\end{array}$ & 1 & 200 & N/A & N/A & $\mathrm{BO},[5]$ \\
\hline April 17, 1981 & $\begin{array}{l}\text { Moved along Baitarani river, BD. Hit villages of } \\
\text { Kapundi, Erandi, Dhanbeni and Rengalbeda. }\end{array}$ & 1 & 120 & N/A & N/A & [5] [39] \\
\hline April 12, 1982 & Rangpur and Gaibandha Boarder, & 1 & 23 & N/A & N/A & $\mathrm{BO},[5]$ \\
\hline April 09, 1983 & Jessore, & 1 & 16 & N/A & N/A & $\mathrm{BO},[5]$ \\
\hline April 23, 1983 & $\begin{array}{l}\text { Raghunathpur village of Kutubpur union in } \\
\text { Fatullah, }\end{array}$ & 1 & 2 & N/A & N/A & $\mathrm{BO},[5]$ \\
\hline April 24, 1983 & Rupsha under Khulna dist., & 1 & 25 & N/A & N/A & BO, Ittafaq, [5] \\
\hline April 14, 1986 & evening Borni of Tongipara, & 1 & 120 & N/A & N/A & $\mathrm{BO},[5]$ \\
\hline April 26, 1989 & Daulatpur-Saturia, Manikgonj & 1 & 1300 & 12000 & 120000 & $\mathrm{BO},[5][18][22][28][44]$ \\
\hline April 20, 1990 & Taras, Ullahpara and Shahazadpur in Sirajganj, & 1 & 76 & N/A & N/A & [9] [33] \\
\hline April 29, 1990 & Sirajganj, & 1 & 19 & N/A & N/A & [9] [33] \\
\hline March 31, 1991 & Champak in Comilla, BD & 1 & 18 & N/A & N/A & $\mathrm{BO},[5][33]$ \\
\hline May 07, 1991 & $\begin{array}{l}\text { Between Ghorashal, Tongi, Joydevpur and } \\
\text { Gazipur, }\end{array}$ & 2 & 121 & 300 & 12000 & $\mathrm{BO},[5][33]$ \\
\hline May 18,1991 & Gournadi in Barisal, & 1 & 50 & N/A & N/A & $\mathrm{BO},[5][33]$ \\
\hline April 22, 1992 & N/A & 1 & 25 & N/A & N/A & $\mathrm{BO},[5][33]$ \\
\hline Jan 09, 1993 & North-east Bangladesh & 1 & 76 & N/A & N/A & {$[5]$} \\
\hline April 09, 1993 & N/A & 1 & 145 & N/A & N/A & [5] [29] \\
\hline May 13, 1993 & Begumganj, Noakhali & 1 & 50 & 356 & 4000 & $\mathrm{BO},[5]$ \\
\hline April 08, 1995 & $\begin{array}{l}\text { Lohaganj, Serajdikhan and Srinigar in } \\
\text { Munshiganj dist., }\end{array}$ & 1 & 40 & N/A & N/A & $\mathrm{BO},[5]$ \\
\hline Sep 28, 1995 & Jamalpur-Northern Bangladesh & 1 & 5 & 125 & 1600 & [5] \\
\hline May 13, 1996 & $\begin{array}{l}\text { Madarganj, Gopalpur, Kallhati, Basail, Shakhipur } \\
\text { and Mrizapur in Jamalpur and Tangail }\end{array}$ & 1 & 700 & 32000 & 100000 & $\begin{array}{l}\text { BO, DMB SitReport-1996, } \\
{[5] \text { [43] }}\end{array}$ \\
\hline Oct 12, 1997 & Dhaka-Gazipur & 1 & 35 & 2500 & 51110 & [5] \\
\hline April 08, 1998 & Nilphimari, & 1 & 21 & 0 & 0 & $\mathrm{BO},[5]$ \\
\hline May 19, 1998 & Dhaka-Sirajgonj & 2 & 25 & 175 & 5000 & Ittefaq, [28] \\
\hline March 26, 1999 & Panchagarh & 1 & 2 & 60 & 1500 & BO, Ittefaq, \\
\hline Sept 19, 2000 & Savar-Gazipur & 1 & 10 & 50 & 8000 & Ittefaq \\
\hline May 04,2003 & Brahmanbaria & 1 & 20 & 200 & N/A & BSS, Ittafaq, UNB, \\
\hline April 14, 2004 & Netrokona-Mymensingh & 1 & 111 & 3500 & 16000 & Daily Star, [5] [28] [35] \\
\hline March 20, 2005 & Gaibandha \& Rangpur, Netrokona & 3 & 133 & 1408 & 26000 & $\begin{array}{l}\text { BSS, Ittefaq, BMD SitRepot- } \\
2005 \text {, UNB, [28] }\end{array}$ \\
\hline March 04, 2006 & Bagerhat District in southern part of Bangladesh & 1 & 4 & 537 & 1600 & BSS, Ittafaq, UNB, \\
\hline March 04, 2006 & Dumuria sub-district of Khulna & 1 & 1 & 35 & 1000 & BO, Ittafaq \\
\hline Oct 15, 2007 & Barisal Gopalganj and Bhola & 3 & 7 & 57 & 3000 & BSS, UNB, \\
\hline Oct 10, 2007 & Tahirpur, northern Sunamganj District & 1 & $\mathrm{~N} / \mathrm{A}$ & 25 & 176 & BSS, Ittafaq, UNB, \\
\hline Oct 15,2007 & $\begin{array}{l}\text { Deawanganj sub-district in north-central } \\
\text { Jamalpur District. }\end{array}$ & 1 & $\mathrm{~N} / \mathrm{A}$ & 7 & 800 & BO, BSS, Ittafaq, \\
\hline May 05,2008 & Barisal and Magura districts of Bangladesh & 2 & 2 & 70 & N/A & BO, Ittafaq, UNB, \\
\hline Feb 17, 2010 & Maheshpur, Khulna & 1 & 1 & 150 & 5200 & BSS, Ittafaq, UNB, \\
\hline April 04, 2011 & $\begin{array}{l}\text { Northern Bangladesh northern districts of } \\
\text { Jamalpur, Thakurgaon, Sherpur, Mymensingh, } \\
\text { Gaibandha, Joypurhat and Bogra }\end{array}$ & 5 & 12 & 150 & 1000 & $\begin{array}{l}\text { BO, DMB SitRepot-2013, } \\
\text { BSS, Ittafaq. }\end{array}$ \\
\hline March 22, 2013 & $\begin{array}{l}\text { Bijoynagar and Akhaura, } \\
\text { Brahmanbaria Sadar Upazilas }\end{array}$ & 1 & 31 & 500 & 1000 & $\begin{array}{l}\text { BSS, Ittafaq, DMB SitRepot- } \\
\text { 2013, UNB, }\end{array}$ \\
\hline April 27, 2014 & Northern Bangladesh & 1 & 20 & 1000 & 7250 & $\begin{array}{l}\text { BSS, Daily Star, Ittafaq, } \\
\text { UNB, }\end{array}$ \\
\hline Total & & 116 & 9667 & 74702 & 586306 & \\
\hline
\end{tabular}

Key:

BDG: Bangladesh District Gazetteer; BMD: Bangladesh Meteorological Department; BO: Bangladesh Observer; BSS: Bangladesh Sangbad Sangstha; DDG. Dhaka District Gazetteer; DMB: Disaster Management Bureau; PO: Pakistan Observer; SitReport: Situation Report; UNB: United News of Bangladesh. 


\subsection{Extremely Violent Tornadoes in Bangladesh}

\subsubsection{The Daulatpur-Saturia Tornado, 1989}

Killing an estimated 1,300 people (BMD 1989, BO, [5] [18] [22] [28] [44]) in a matter of minutes, the DaulatpurSaturia tornado is believed to be the deadliest tornado on world record [28] [44]. The twister hit the Manikganj District in Bangladesh, on April 26, 1989 at around 6:00 p.m. local time. Overall, around 12,000 people [28] [44] were injured by the tornado in the towns of Saturia and Manikganj. The towns were completely destroyed, and a total of 120,000 people were homeless (BO, BMD 1989, [28] [44]).

\subsubsection{East Pakistan Tornado, 1969}

The 1969 East Pakistan tornado hit the highly populated area on April 14 at Dhaka region (PO, [5] [30]). The tornado struck in the northeastern suburbs of the town Dhaka, killed an estimated 660 people and injured 4,000 population (PO, [5] [30]). Later about 109 people were added with the estimated 660 people dead instantly from the injured [30]. As horrible as that tragedy was, it was only one of two deadly tornadoes to hit Bangladesh on April 14, 1969. A second twister [30] touched down in the Homna Upazila, part of the Comilla District in Bangladesh in the same day. Mowla [30] claims that the tornadoes were part of the same storm system, but separate from one another. Overall, once the estimated 263 deaths [30] from the Homna Upazila tornado were added into the 660 from the Dacca twister, the total death toll reached to 992 (PO (15-20 April-1969), [5] [30]).

\subsubsection{Madarganj-Mrizapur Tornado, 1996}

As one of the most recent deadliest tornadoes in the history, an estimated 700 people [33] perished after a huge tornado touched down from Madarganj to Mrizapur in Bangladesh on May 13, 1996 (BO, [33] [5]). While the numbers of injuries were not known, the 700 deaths from the single twister make this the second single deadliest tornado on record [28] [44]. As the tornado traveled south from Madarganj to Mirzapur in Bangladesh, a distance of over 100 kilometers, it also destroyed an estimated 30,000 homes, 1600 Cattle were lost [33] and left more than 30000 people injured (BMD, 1997 [43] [44]).

\subsubsection{The Manikganj, Singair and Nawabganj Tornado, 1973}

Named after the three main areas that were destroyed in its path, the Manikganj, Singair and Nawabganj Tornado took the likes of 681 people on April 17, 1973 (BO, [5] [20] [28] [44]). Overall, the wide tornado destroyed the greater part of nine towns, including wiping out the entire large village of Balurchar. The 681 fatalities rose as much as over 1,000 in some unofficial death tolls and was likely the result of the massive size of the twister. According to reports, two tornadoes combined to form one massive tornado, which then went on a path of destruction throughout Bangladesh. Overall, the Manikganj, Singair and Nawabganj Tornado, using the confirmed death toll of 681, ranks as the fourth [28] [44] deadliest in world history.

\subsubsection{The Narail-Magura Tornado, 1964}

Despite occurring only back on April 11, 1964, the NarailMagura tornado hit the two district partially and leave a wide devastating footage. The twister is known widely for the killing of an estimated 500 people [5] [28] [44], though the total death toll could be much more [44]. The Narail-Magura Tornado hit the two district laterally and destroying a total of seven villages. One village, Bhabanipur, was home to 400 citizens all of which were either confirmed dead or never seen or heard from again after the disaster [44]. The Overall, as many as 1,400 were either killed or went missing since the incident [28] [44].

\subsubsection{The Madaripur-Shibchar Tornado, 1977}

As yet another deadly tornado has struck in Bangladesh as known the Madaripur-Shibchar Tornado which demolished an estimated 500 lives when it hit on April 1, 1977 (BO, [1] [33] [28] [44]). The path of destruction as the twister traveled from the one town to another, and ravaged the neighborhood was vast with thousands injured [28] [44]. In addition to claiming lives, the Madaripur-Shibchar Tornado leveled the area in both of the villages in towns. All buildings, homes, trees and other structures in both Madaripur and Shibchar were completely destroyed by the tornado (BO, [44]).

\subsection{Frequency of Tornado in BD}

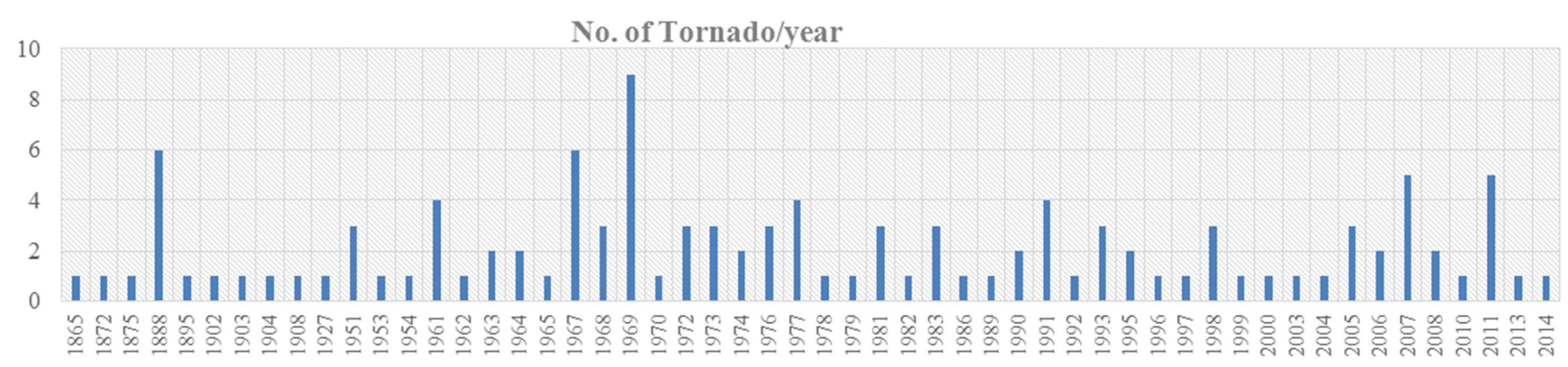

Figure 3. The frequency of fatal tornado incidents in Bangladesh.

The review period of the study was 1865 to 2014 as the published evidence (Table 2) available from various important known sources. The available data produces the above graph presenting as the frequency of the fatal tornados during the period on the annual basis as with the minimum life loss, more destructive in nature causes for more fatalities, 
injuries and vastly damaged per events. There are numerous tornado events count on various sources and published but without human fatalities. We carefully deduct them from the list. The prepared database of the fatal tornados produced the above scenario (Figure 3) that represent the number of fatal incidents in each year. The graph shows (Figure 3) the 70's decade is more frequent then shows a nominal in 80 's to 89 and again severe in the 90's to 2000 and with the increasing trend at 2001 to 2011 . The trend of the graph represents the incidents gradually more frequent after the period of 1990 . Figure 3 shows that 1969 was the most vulnerable in terms of fatal tornado events.

\subsection{Tornado Damages}

Tornado damages are caused by the high wind speed and high difference in atmospheric pressure between the tornado and its surroundings. The rotating winds can knock down weaker structures, and the extremely low pressure inside the tornado generates strong pressure differences between the inside and outside of buildings. This pressure difference causes roofs to be lifted and removed. The high winds picked up smaller objects including small structures, animals, people, cars, and especially mobile homes, and can carry these objects up to several kilometers (earthsci.org/tornado damage). The rural community people from the underdeveloped nations like Bangladesh, India Nepal, and Bhutan had been the most sufferer of the tornado incident due to the poor construction materials in housing. The high pressure of tornado wind easily torn up the poor rural infrastructure made of bamboo, simple wood and corrugated iron, aluminum or copper sheet. The debris picked up by the winds become rapidly moving projectiles that can become lethal when hurled against a human body (earthsci.org/tornado damage). The Figure 4 shows the fatal tornado incidents occurred in the region from 1838-2005 [5] as the base of the tornado related death tolls.

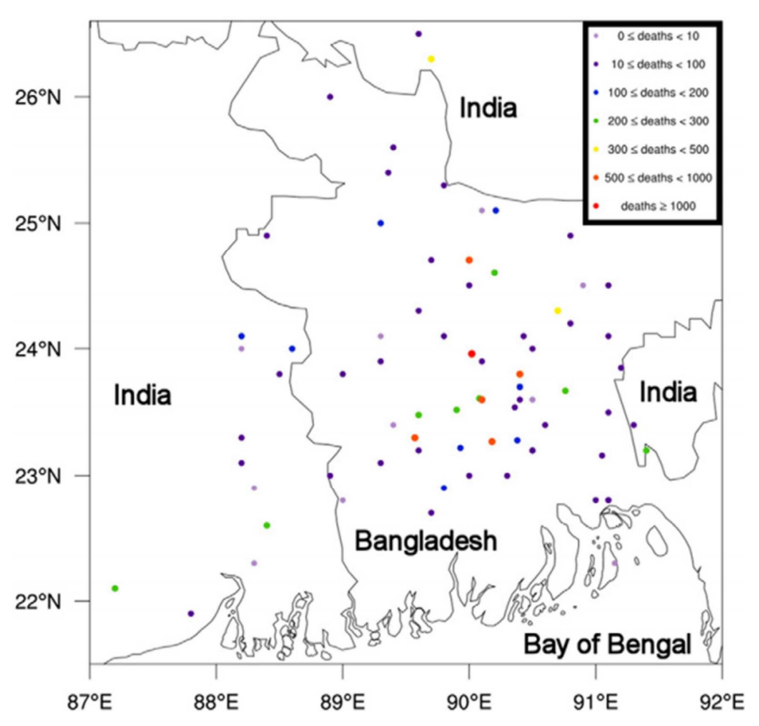

Figure 4. Location of tornado related deaths over Bangladesh \& East India from 1838-2005. [C D. Bikos et al.].

\subsection{Impacts of Tornadoes}

\subsubsection{Fatalities of Tornado}

Ono [34] provided three potential explanations for a higher percentage of tornado fatalities in Bangladesh: (1) Tornadoes in Bangladesh are so violent that most of them result in fatalities, (2) Poorly constructed housing commonly throughout the country increases the death toll, and (3) there are many tornadoes occurring in Bangladesh that remain unreported. The high population density, a paucity of preparedness programs - including tornado forecasting and warning systems - and houses made with tin built on elevated ground are also associated with the higher incidence of tornado-related deaths in Bangladesh [34]. Tornadoes dismantle tin/corrugated iron sheets like paper, turning them into airborne missiles that can cause severe injury and even to death [35].

\section{FATALITIES TREND/YEAR}

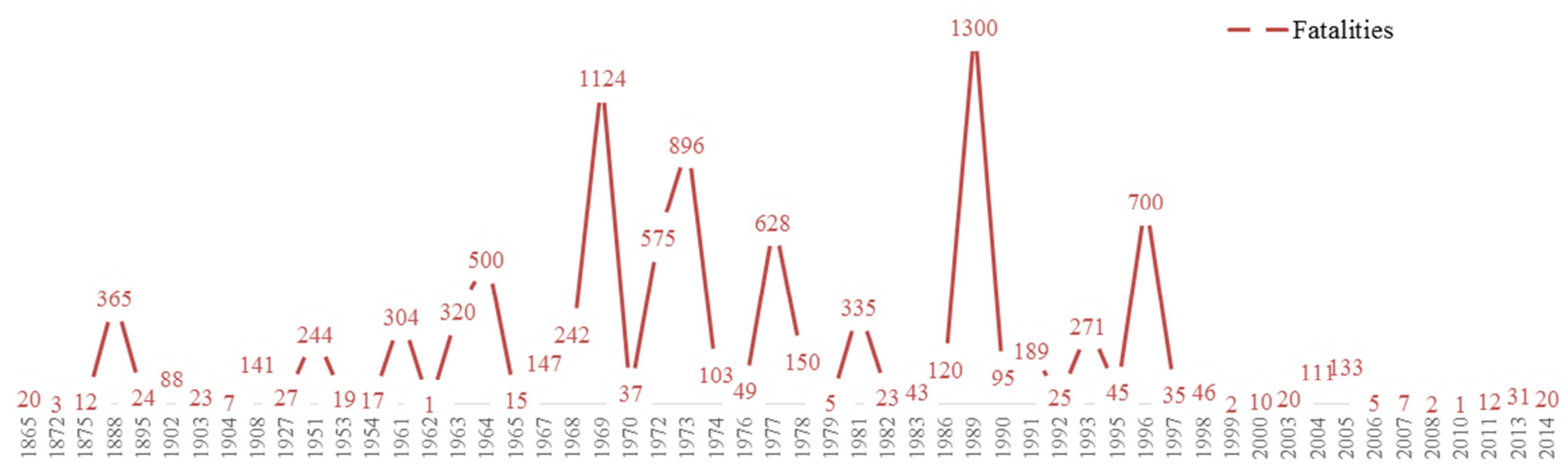

Figure 5. Fatalities trends of tornados in Bangladesh.

The above graph (Figure 5) represents the number of life losses due to the fatal tornado incidents that occurred in the region from the historical ages. It depicts a picture that a decade of 1970's was the most miserable in the histories.
Then it is going in the downward for the next decade and again rising in certain level. As we know the world deadliest tornado (Daulatpur-Saturia, 1989) incident had been occurring at this time (BO, [5] [18] [22] [28] [44]). After then 
the death toll has been decreasing, but the tornado incident was more frequent than before.

\subsubsection{Human Injuries Trends in Tornados}

The line graph (Figure 6) shows the tornado related human injury during the study period. The injury incidents have escalated in the 1970 decades to near about to 15000 and again in 1989's it try to reach its previous station. But in 1996 's the injury tolls of the fatal tornados went beyond its all anticipation due to wide affected area (BO, DMB SitReport-1996, [5] [43]). It left more than 32000 human lives injured in the affected area (BMD, 1997 [5]).

\section{Population Injury/Year}



Figure 6. Human Injured trends of tornados in Bangladesh.

\subsubsection{Human Lives Affected Scenarios in Tornados}

The affected population curve (Figure 7) represents the gradually increasing trend of the affected population from the early ages. In 1960's and 70's the more people affected by the single occurrence and within the time the destruction pattern increases. In this decades, more than two deadliest tornado of the history have been occurred. So why, the tornado affected the maximum population in the period. At the same time (1960-1972) the country (Bangladesh) was also in the most vulnerable situation in economically as well as politically. In 1989 more than 12 million people (BMD, 1990, BO, [18] [22] [28] [44]) affected by single tornado incident (Daulatpur-Saturia Tornado, 1989) then decrease in the next decade and again up surged sharply and affected more than 10 million people in 1996 [33]. The scenario shows that the situation was more vulnerable. The gap between the most affected tornado incident declining within the time later in the decade of 90 's.



Figure 7. Scenario of affected population trend due to disastrous Tornado incidents.

\subsubsection{Effect of Tornado on Local Water System}

According to Doswell [10], heavy precipitating (HP) are probably the most common form of Supercells. These storms doesn't only occur in the humid sector but also into the high plains. For the HP Supercell, heavy precipitation is experienced, with the meso-cyclone embedded within the precipitation region of the storm, as seen in the precipitation surrounding the wall cloud. However, while classic supercell features moderate precipitation, light to no precipitation is experienced in the meso-cyclone. During the collapse of a classic supercell, the meso-cyclone may fill with precipitation [10]. This precipitation mixed up with the local water body and the crop land, also with the other local water system. All of this sudden water is a curse for local water system and crop production. It also may create instant crisis of the local drinking water system. The women and children are the most affected one in the arising vulnerable situation. 


\section{Mitigation of Tornado Disasters \& Required Actions}

\subsection{Safety During the Tornados}

Tornados are instant natural events carry on extreme catastrophe within a very few moments. Nelson [32] state that it is hard to forecast earlier before enough time. If you are under a tornado warning, seek shelter immediately! Most injuries associated with high winds are from flying debris. So remember to protect your head at first anyhow.

If you are in:

A structure (e.g. residence, small building, school, nursing home, hospital, factory, shopping center, high-rise building)

Then:

- Go to a pre-designated shelter area such as a safe room, basement, storm cellar, or the lowest building level

- Keep yourself away from corners, windows, doors, and outside walls. Put as many walls as possible between you and the outside.

- Get under a sturdy table and use your arms to protect your head and neck.

- Put on sturdy shoes \& try to save your backbone.

- Do not open windows.

If you are in:

The outside with no shelter-

Then:

- Immediately get into a vehicle, buckle your seat belt and try to drive to the closest sturdy shelter.

- If your vehicle is hit by flying debris while you are driving, pull over and park.

- Stay in the car with the seat belt on. Put your head down below the windows; cover your head with your hands and a blanket, coat or other cushion if possible.

- If you can safely get noticeably lower than the level of the roadway, leave your car and lie in that area, covering your head with your hands

- Do not get under an overpass or bridge. You are safer in a low, flat location.

- Never try to outrun a tornado in urban or congested areas in a car or truck. Instead, leave the vehicle immediately for safe shelter.

- Watch out for flying debris. Flying debris from tornadoes causes most fatalities and injuries.

\subsection{Mitigation of Tornado Disasters \& Required Actions}

The Tornado creates a disastrous situation instantly within a very few minutes. It's very hard to predict early [32]. To mitigate the tornado disaster's risks, the overall capacity of the Bangladesh Meteorological Department (BMD) should be enhanced. It really needs to develop an effective early warning system for extreme natural events. Because tornadoes can strike anywhere and anytime there are thunderstorms. The best mitigation is for an educated populace to be aware of the conditions under which tornadoes develop and heed any tornado watches or warnings that are issued by a responsible agency, and practice the tornado safety tips listed above. The only other mitigation that can reduce the damage produced by tornadoes is maintaining proper building codes that require structures to be constructed with extra reinforcing of wood frames and masonry.

In the face of increasing extreme disastrous events and the vulnerability to climate change, accurate forecasts/warnings system, more precise application of climatic data and information based on the local climatic scenario chart should be developed. Developed the capacity of the specific Govt. agency so that they can ensure the instant food security and other emergency responses. Bangladesh is an agro-based country. So that for the sustainable socio-economic development, seasonal climate forecast for agriculture and other livelihood activities is important. The capacity enhancement of climate scenario development in local perspective for proper adaptation and mitigation of climate change impact are very important for BMD.

For the overall capacity enhancement of Govt. as well as the BMD in forecasting along with institutional up-gradation, the following initiatives should be taken into consider:

Institutional up-gradation: Quality performance is the most important component for the delivery of quality service. In terms of technological development, the initiatives have been undertaken at the moment to develop the infrastructural facilities and human capacity in BMD. But to uphold the efforts of sustainable development in the meteorological service, it is imperative that quality human resources should be integrated with the system. For upholding BMD's mandate in the new perspective of climate change and disaster risk reduction efforts of Government, it should be well equipped with the highly advanced technology, quality manpower along with the institutional expansion for the operation and maintenance of Numerical Weather Prediction (NWP), climate modeling, seasonal forecasting and more accurate and timely early warning system.

Infrastructural development: For the infrastructural development BMD should have to take the following initiatives:

- Development of Human Capacity on Operation of Weather Analysis \& Forecasting

- Preparation of Wind Map of Coastal Areas/Feasible Areas of Bangladesh for Assessing Power Generation Potential

- Up-gradation of Agro-meteorological Services

- Improvement \& Relocation of Dhaka Meteorological Radar System for operation in aviation and Riverine Sectors and Protection of Urban System against National Disasters

- Numerical Weather Prediction System

- Up-gradation of surface observatories through Establishment of Automatic Meteorological Observing System \& Wind Profilers

- To protect the local water system the sewerage pipeline of storm water should be built.

- The Tornado risk mapping zone should be developed to minimize the damages. 


\section{Conclusion}

According to the geographical location Bangladesh is extremely disaster prone country where tornado is one them. During the time of our study we found that it faced more tornado incidents as per the local information. But most of them were unreported due the improper documentation and minimum hazards. As per an aged local stakeholder, the so called print, electronic and broadcast media only cover the incidents whose were extremely devastating. Another major cause is tornado strike for the very short period of time so that most of the time local people did not recognize the incidents. So why, most of them were remain unreported. In our study we only consider the fatal tornado that cause the severe hazards. So a large number of the tornado remain undocumented. It require the further critical study to cover them for the proper documentation. From the study, we can see that frequency of the tornados is increasing step by step. Before the 1987 every year the tornado was not common, but the last few years, we faced at least one tornado in every year sometimes more than one. The devastation of this occurrence is increasing gradually. A lot of people claim for injured and death fatalities previous but we see 2004 faces a lot of sufferings of the people compared to the years before. It indicates that the population is higher, so the exposed number is tall and the system is upgraded that's why the death and injured is less than before. It's a great concern for our people. We should aware about the future tornado from this current situation. We are in a gap of mass destruction of tornados, so we should practice all of the curative action. If we can take all the precautionary management for tornado action, then we can minimize the loss of stroke. Overall, a lot of continuous and intense work is required to fulfill the gap and minimize the loss.

\section{Acknowledgements}

We would like to thanks to our honorable supervisor Professor Dr. M. Shajahan Mondol, Professor, IWFM, BUET for his continued inspiration and direction. Our heartfelt thanks to Dr. Ashraf Dewan, Curtin University, Australia for the valuable resource content to smooth way out of the work. Special gratitude goes to Arjumand Habib, Director of Bangladesh Meteorological Department in Dhaka for her resource information and help to accomplice the work. We are grateful to the authors, the publishers and the websites of whose works we have cited the excerpts. We also pleased to thanks to our friends and classmates for their immense cordial assistance.

\section{References}

[1] Ahmed, J., 1977. A Case Study on the Tornado That Occurred in Madaripur on 1 April 1977. Director, Bangladesh Meteorological Department, Dhaka, Bangladesh (Available from Bangladesh Meteorological Department, Meteorological Complex, Agargaon, Dhaka-1207, Bangladesh)
[2] Ahmad, N., and Kabir, S. A. 2001. "Tornadoes in Bangladesh." In Disaster in Bangladesh: Asian Development Bank, Country Environmental Analysis Bangladesh, 2001

[3] Ahmad, N., and Kabir, S. A. 2001. "Tornadoes in Bangladesh." In Disaster in Bangladesh: Selected Readings, K. Nizamuddin (ed.), pp. 137-145. Dhaka: DRTMC, University of Dhaka

[4] Bangladesh Disaster report 2013, Disaster Management Bureau of Bangladesh. Available at: <http://www.dmb.gov.bd $>$ Accessed 15 November, 2015

[5] Bikos, D., Finch, J., and Case, J. L., 2015. The Environment associated with the significant tornadoes in Bangladesh. Atmospheric Research 167 (2016) 183-195

[6] Brooks, H., Doswell, C. A., 2001. Some aspects of the international climatology of tornadoes by damage classification. Atmos. Res. 56, 191-201

[7] Choudhury, A. M., Quadir, D. A., Neelormi, S., and Ahmed, A. U., 2003. Climate Change and Its Impacts on Water Resources of Bangladesh, Asian ICS Agro Dev. International, Islamabad, pp. 21-60

[8] Chowdry, M. H. K., Karmakar, S., 1986. Premonsoon nor'westers in Bangladesh with case studies. Proc. Seminar on Local Severe Storms, Dhaka, Bangladesh Meteorol. Dep, pp. $147-166$

[9] Das, R. C., Munim, A. A., Begum, Q. N., Karmakar, S., 1994. A diagnostic study on some local severe storms over Bangladesh. J. Bangladesh Acad. Sci. 18 (1), 81-92

[10] Doswell, C. A. III, and D. W. Burgess, 1993: Tornadoes and Tornadic Storms: A Review of Conceptual Models. The Tornado: Its Structure, Dynamics, Prediction, and Hazards, Geophysical, Monograph 79, Amer. Geophys. Union, 161-172

[11] Finch, J. D. (2005) "Bangladesh and East India Tornadoes: Background Information." Available at: $<\mathrm{http}$ //bangladeshtornadoes.org/bengaltornadoes.html $>$ Accessed on June 3, 2015

[12] Floyd, J., 1839. Account of the hurricane or whirlwind of the 8th April 1838. Am. J. Sci. Arts 36, 71-75

[13] Fujita, T. (1971). "Fujita Tornado Damage scale" at University of Chicago. Available at: $<$ http://www.spc.noaa.gov/faq/tornado/f-scale.html $>$. Accessed on 28 November, 2015

[14] Fujita, T. (1973, April). "Tornadoes around the world." Weatherwise, pp. 56-62

[15] Golden, J. H., and C. R. Adams. 2000. "The Tornado Problem: Forecast, Warning, and Response." Natural Hazards Review, 1: $107-118$

[16] Goldar, R. N., Banerjee, S. K., Debnath, G. C., 2001. Tornado in India and neighborhood and its predictability. Sci. Rep. 2 (2001) (21 pp., Indian Meteorol. Dep., Pune, India)

[17] Ghosh, A. K., 1982. A tornado over Orissa in April 1978. Mausam 33 (2), 235-240

[18] Grazulis, T. P., 1993. Significant tornadoes. Environmental Films, St. Johnsbury, VTpp. 1680-1991 (1326 pp.)

[19] Hasan, M. R. (1979): Tornado over Bangladesh. Bangladesh Met. Dept. Memo-1979 
[20] Hasan, M. R., 1986. Tornado over Bangladesh. Proceedings of the Seminar on Local Severe Storms. 17-21 January 1986, Dhaka, Bangladesh, pp. 114-117

[21] Haque, C. E. 1995. "Climatic Hazards Warning Process in Bangladesh: Experience of, and Lessons from, the 1991 April Cyclone." Environmental Management, 19: 719-734

[22] Hossain, A., Karmakar, S., 1998. Some meteorological aspects of the Saturia tornado, 1989-a case study. J. Bangladesh Acad. Sci. 22 (1), 109-122.

[23] IFRC (International Federation of Red Cross and Red Crescent Societies) (2005) 'Tornado information bulletin no. 1'. IFRC, Bangladesh. Available

http://www.reliefweb.int/rw/rwb.nsf/db900sid/LSGZ-

6ASF7Q? OpenDocument\&cc=bgd. Accessed on 9 August 2015

[24] Islam N. and Mannan A., 2008: 'Characteristics of Thunderstorms occur pre-monsoon period in Bangladesh' published in the 'Proceedings of SAARC Seminar on 'Nor'wester and Tornadoes over SAARC Region and their Forecasting \& Preparedness', SAARC Meteorological Research Centre (SMRC), Dhaka, pp 86-93

[25] Islam Tariful A. K. M. The Aftermath of Tornado in Brahman Baria, 22 $2^{\text {nd }}$ Mar 2013. Brief Assessment Report of Comprehensive Disaster Management Program (CDMP II). Ministry of Disaster Management \& Relief, Govt. of Bangladesh. Apr 2013

[26] Karmakar, S. (1989). Natural Disasters in Bangladesh: A Statistical Review. Paper presented at the Seminar on Impact of Information towards Mitigation of Natural Disasters, held on January 7-8, 1989 at BANSDOC. Dhaka, Bangladesh

[27] K. Nizamuddin (ed.), Selected Readings, pp. 137-145. Dhaka: DRTMC, University of Dhaka

[28] List of Asian tornadoes and tornado outbreaks. Available at: $<\mathrm{http}$ ///en.wikipedia.org/wiki/List_of_Asian_tornadoes_and_tor nado_outbreaks $>$. Accessed on 25 November 2015

[29] Misra, P. K., Goldar, R. N., Banerjee, S. K., 1996. Devastating tornado of Kandi (9 April 1993)-a case study. Mausam 47 (3), 301-306

[30] Mowla KG. 1986. A scientific note on the nor'wester of 14th April, 1969 in Bangladesh. In Proceedings of the Seminar on Local Severe Storms. 17-21 January 1986, Dhaka, Bangladesh

[31] Nandi, J., Mukherjee, A. K., 1966. A tornado over northwest Assam and adjoining West Bengal on 19 April 1963. Indian J. Met. Geophys. 17, 421-426

[32] Nelson, S. A. (2004). Exceptional Weather, EENS 204, Naturals Disasters, Tulane University. Available at: $<$ http://www.tulane.edu/ sanelson/Natural_Disasters/exceptwea th.htm>. Accessed at December 12, 2015

[33] Ono, Y., 1997. Climatology of tornadoes in Bangladesh, 19901994. J. Met. 22 (222), 325-340

[34] Ono, Y. 2001. "Design and Adoption of Household Tornado Shelters to Mitigate the Tornado Hazard in Bangladesh" An unpublished Ph. D. Dissertation, Kent State University, Kent, Ohio.

[35] Paul B K, and Bhuiyan R H, April 2004. Tornado in NorthCentral Bangladesh: A Case for Introducing Tornado Forecasting and Warning Systems, Natural Hazards Center or the University of Colorado

[36] Paul, B. K. 1998. "Coping with the 1996 Tornado in Tangail, Bangladesh: An Analysis of Field Data." The Professional Geographer, 50: 287-301

[37] Pedler, A., 1888. Meteorological conditions accompanying the Dacca tornado. J. Asiat. Soc. Bengal 47, 185-203

[38] Peterson, R. E., and Mehta, K. C. 1981. "Climatology of Tornadoes of India and Bangladesh.” Arch. Meteor. Geophysik, Bioklim, 29B: 345-356.

[39] Petersen, R. E., Mehta, K. C., 1995. Tornados of the Indian Subcontinent. 4, 2077-2081

[40] Relief Web. 2004. "Bangladesh: Tornado Information Bulletin No. 2/2004." September 16, 2004

[41] RIANOVOSTI (Russian Sputnik News), 2010. "Tornado formation info-graphics". Available at: http://sputniknews.com/infographics/20110802/160275534.html. Accessed on 14 November 2015

[42] Saha, K., 1971. Tornadoes in India. Vayu Mandal. 1 pp. 84-87.

[43] Schmidlin, T., and Ono, Y. 1996. Tornadoes in the Districts of Jamalpur and Tangail in Bangladesh. NHRAIC, University of Colorado, Boulder, CO. QR90

[44] "The-worst-tornadoes-in-history" (2014). Available at: $<\mathrm{http}: / /$ www.ranker.com/list/the-worst-tornadoes-inhistory/drake $>$. Accessed on 02 September, 2015

[45] Tornado formation, 2013. Available at: $<$ http://www.theborneopost.com/2013/05/22/massive-tornadostrikes-oklahoma-city/tornado-formation.> Accessed on 22 November 2015

[46] "Tornado project" (2013). World's most deadly tornados database. Available at: http://www.tornadoproject.com/faves/faves.htm\#top Accessed at October 21, 2015

[47] Tornado strike- how do they work, 2014. Available at: $<$ http://whyfiles.org/2014/tornadoes-strike-again-how-do-theywork>. Accessed on October 28, 2015

[48] Weather Underground/History, (2015). Deadliest Tornedos in Bangladesh. Available at: http://www.w underground. com/history Accessed 12 November, 2015

[49] World Bank, (2004). "Bangladesh Country Report 2004Disaster and hazards." Available at: http://www.worldbank.org/countries. Accessed on November 15,2015

[50] Yamane, Y., Hayashi, T., Dewan, A. M., Akter, F., 2010. Severe local convective storms in Bangladesh: part I.: climatology. Atmos. Res. 95 (4), 400-4018 